REFLECTIONS:

NEUROLOGY AND THE

HUMANITIES

Section Editor

Michael H. Brooke, MD

\section{The Button}

Michael J. Doherty, MD

Address correspondence to Dr. Michael J. Doherty, Swedish Epilepsy Center, 801 Broadway Suite 901, Seattle, WA 98122 michael.doherty@swedish.org
If you look out our shop window and down to the river, you see most of the Button. It's a spectacular place, a round pool, deep, fed by a small run and fall that meets it on a tangent. It looks like a giant ripped it from his shirt, and thumbed it hard into the hillside right down to the riverbed. Rainbow and cutthroat trout thrive in it, and two small islands, far taller than they are wide, poke out in the middle.

Two hollow-trunked Doug firs used to anchor each of the islands, but floods and wind several years back snapped them low. The one falling took the other out with it. Now the remaining skeleton trunks are bare of bark, and their mad roots trap boulders, or dig fingers into the pool.

With spring melt, the Button turns into an angry whirlpool, and all kinds of other trees and logs pile and shift between the islands; they help scour a curved cliff wall on one side. You can hear the groans and cracks of the wood or ice breaking up in spring, moving their way downstream. And in summer, with the shop door open, the shouts and hollers of the kids on the rope swing or cliff echo on up to us.

The Button is on a blue-ribbon catch-and-release river that runs through Sunder's place before it shoots through town. After Gracie died, Jim and Kelly put a memorial bench up on the cliff overlooking it. It was Gracie's favorite place. She learned to swim there, like most of us, cold and goose bumped, and it was fitting they spread her ashes there. I had seen them do it, through the binoculars, a little puff of smoke off the cliff, down into the pool. We see Jim up on that bench now and then looking at the fishermen, or perhaps not. Our binoculars aren't so good.

Gracie's death didn't sit well with anyone, but Jim took it the hardest. The farm suffered; he left his corn on into spring and missed all the hay. The starlings, cowbirds, and crows squabbled among his fields. Come winter snow and ice, there was never enough to hide the stalks and scotch thistle. Fox, deer, and coyotes thrilled in all of it.

Jim grew his beard and hair; he got feral. Kelly had done better; she volunteered in the school. She first worked with the fifth graders, just like Gracie was, but they subbed her into a first grade class, and she liked that more. She put a new bumper sticker on her truck: "Save the world, learn to read."

It was no surprise when Jim came through our door. We'd seen most all there was to see, and sooner or later a man looks at himself and knows he needs a haircut. And Leo had money on it for late spring. I bet fall. Loser had to cut and pay.

"Leo, Sol," he nodded to each of us.

"Jim, it's good to see you. What can we do for you?"

"I want it off. Make me look young." He half smiled. I pointed toward the chair. He hung his coat and hat with ours, and all the others left behind.

"Beard too?"

"Yep, all of it."

Leo turned on the music. The college kids leave us CDs; we play 'em because we need their business, they want to hear it, and neither of us cares for radio or anything that reminds us of the past. The kids are young and don't give a rat's ass, and they tell us about their girls and sometimes it's good to hear that. Sometimes they ask us for advice, as if old barbers have advice worth taking.

"What are we listening to, boys?"

Leo looked at the case, tilted his head, and squinted to get the bifocals working. "Someone or something called Mazzy Star. You want something else?" He flicks through the CDs, reading the names slow and exaggerated, like it's the first time he's ever read, pausing between each one, sounding every bit the grandfather he is. "The Feelies, Waterboys, Magnetic Fields?"

Jim laughs. "No, I don't care, so long as there's no politics, preaching, or whining."

I start with the scissors and hack. No other word for it. There were knots in his hair that were best cut, not combed or clipped. Worked as the pain and tremor permitted. Jim looked on at himself in the mirror, or back out the front window, but not at me. I have to concentrate hard so he doesn't see my shakes. It's worse when the kids want flattops.

The door opened and a stranger walked in.

Leo looked up. "Need a cut?"

"I need it cut." He showed the guy the chair, 
spun it just so, and put his hand over the duct-taped part. Leo cracked his rag over the seat and stray hairs blew off into the sunlight.

Leo draped him up and the guy told him what he wanted. And then it was just music and the sounds of our tools, the buzz of the clippers, the scissors.

Leo asked the guy where he's from. Pakistan. And what's he doing way out here? The guy worked at the hospital downtown. He told us his real name and then just to call him Mo. He fished out a card from under the gown just as Leo pulled a comb out of the blue pool of disinfectant.

Leo held his clippers and comb up in the one hand and squinted at the card in the other.

"A brain doctor? Wow. You need to see my friend Sol here. He's got this delusion that one day we might make it rich doing this crap-two old men cutting hair in a small town with a bunch of cheapskate college kids and even more miserable locals. Plus he can't cut straight no more on account of the syphilis and drinking."

"It's Leo you need to see. You know he's blind, right? Cuts by touch alone. He's deaf too. His skills leave a lot to be desired. You're welcome to wait for me while I finish this gentleman ..." My hand was shaking, the straight razor catching the sun; I turn it into a kind of general wave. I think my point was well demonstrated. I do a lot of hand waving. Leo tells me my "gesticulations" make me look crazy.

Jim shifted in the chair. I've got him tilted back and am about to lay on the foam over his face and neck for the straight razor.

“You must be new. Wasn't there that guy downtown, ahh, what's his name, Sol, help me here, tall fella, thick hair with a kid cut, like a caramel apple? Remember- he used to fish the Button. We haven't seen him for a while."

“Duker. Fred Duker,” Jim says. He’s clenched his jaw.

"Yeah, Duker. What happened to Fred Duker, Neurologist?"

Mo answered: "He left. About a year ago."

"What happened?"

"He was upset about a girl that died."

Things tensed up a notch. Leo took his time switching to a number one, the close fence, checked the fit, and moved back. Mo talked on, and in one practiced move, Leo buzzed up a stretch on the back of his neck.

"The girl was very sick, the parents brought her to see Fred. She had a bad headache, but nothing special to him. He sent the child home with her parents, asked them to check on her. Later that night she got a rash, rose-colored spots that turned purple, and she couldn't talk. Spinal meningitis. They called Duker and he told them she needs to go to the ER, right away.”

Leo had stopped cutting.

The music was soft.

I could feel Jim's stubble falling beneath the straight edge. Jim was trying to look at the guy, but the mirror wasn't right.

Mo took his time, talked only when Leo worked the back or sides.

"The horrible part was, the family took her in, but on the way their truck broke. Late at night, no phone, and the girl was getting worse. When they finally get her to the ER, they start everything, the antibiotics, the breathing tube, steroids. But she never got well."

We worked on, and the music helped fill a hole.

"Fred blamed himself. Said he could deal with anything but not sick kids. Said he was done, that he should have told them to call the ambulance, that she might have made it if things were faster, would have given anything to have her come again the first time."

My hand was very steady now, the sharp blade up and off his throat as Jim took a hard swallow. Mo continued.

"He was beating himself up bad. I tell him, Fred, it's not your fault, but he says, 'Mo, you'll know when you've had enough one day too."”

There's not much left to shave; Jim's eyes are wet. I finish, clean the last of the lather, and gave him a new rag to wipe up. He's off the chair now, taller than I remembered. As an afterthought Mo says, "He's all gray now."

After a while Leo spoke slow and deliberate so we all could hear.

"You know Jim, out on those islands, out there in the Button, I was looking there this morning, there's cottonwoods coming up out of the stumps. Nurse logs. That's what tree huggers call 'em."

Jim ran a comb through his hair, slow, swallowed again, looked at himself anew, pulled his coat on.

"I seen them too. They're growing fast. It's no wonder, I mean look at all them seeds floating in the air, and all that good water below to draw on."

The long line of cottonwoods on the far bank bent slightly; fluff was snowing down depending on the breeze.

Jim was youngish again, though he looked very different. He took out his wallet, and I caught a glimpse of a picture-Gracie, him, and Kelly-in the heart of it, stiff like they took the picture at Sears. He paid and tipped his cap to each of us. 
"Leo, Sol ... Mo."

Mo looked up, surprised that Jim would address him.

"There isn't any blame to be had there."

And out Jim walked, across the street, vaulted his fence, and made his way to Gracie's bench. He sat a while looking at the Button. And then the college kids started showing up and Leo wanted his money for lunch and things got busy again, and when I looked up later he was gone. 


\title{
Neurology
}

\author{
The Button \\ Michael J. Doherty \\ Neurology 2007;68;1433-1435 \\ DOI 10.1212/01.wnl.0000268251.87299.70
}

\section{This information is current as of April 23, 2007}

\section{Updated Information \&}

Services

Permissions \& Licensing

Reprints including high resolution figures, can be found at: http://n.neurology.org/content/68/17/1433.full

Information about reproducing this article in parts (figures,tables) or in its entirety can be found online at:

http://www.neurology.org/about/about_the_journal\#permissions

Information about ordering reprints can be found online:

http://n.neurology.org/subscribers/advertise

Neurology ${ }^{\circledR}$ is the official journal of the American Academy of Neurology. Published continuously since 1951, it is now a weekly with 48 issues per year. Copyright. All rights reserved. Print ISSN: 0028-3878. Online ISSN: 1526-632X.

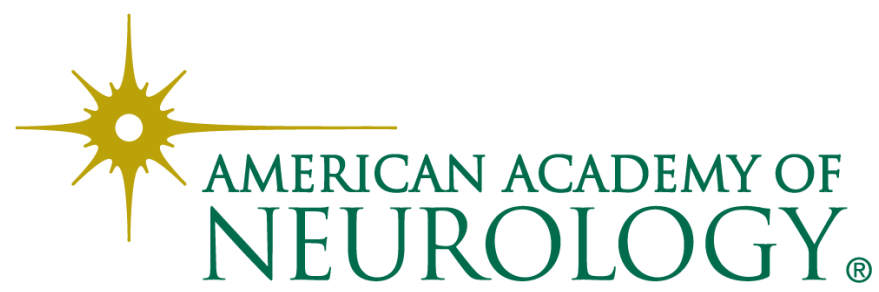

